\title{
Study of D-Dimer Levels in HIV Treatment-Naïve and Treatment Experienced Patients in Port- Harcourt, Nigeria
}

\author{
Akhidue $\mathrm{DO}^{1}$, Akhidue $\mathrm{K}^{2 *}$, Alikor $\mathrm{CA}^{2}$ \\ ${ }^{1}$ Department of Haematology, Federal Medical Center, Yenagoa, Nigeria \\ ${ }^{2}$ Department of Internal Medicine, University of Port Harcourt Teaching Hospital, Port Harcourt, Nigeria
}

DOI: $10.36348 / \mathrm{sb} .2020 . v 06 \mathrm{i} 03.001$

| Received: 24.02.2020 | Accepted: 05.03.2020 | Published: 11.03.2020

*Corresponding author: Akhidue $\mathrm{K}$

\section{Abstract}

Background: Reports suggest that HIV-infected patients have elevated D-dimer levels that may be related to chronic inflammation and coagulation abnormalities. Levels of D-dimer have also been reported to be higher in HIV treatmentnaïve patients compared to treatment- experienced patients. Methods: Eighty (80) subjects attending HIV clinic at the University of Port-Harcourt Teaching Hospital, Port Harcourt, Rivers state who satisfied the inclusion criteria were enrolled into the study. A commercial assay kit; ELISA Kit for D-Dimer (D2D) (manufactured by Uscn Life Science Incorporated $^{\mathrm{R}}$ USA) was used with a TC96+ ELISA microplate reader (manufactured by Ceco diagnostic ${ }^{\mathrm{R}}$ USA) to determine the D-dimer level. CD4 + T-cell count was evaluated using the Partec Cyflow counter-1, a single-platform, three-parameter (SSC plus two-colour fluorescence) desktop volumetric flow cytometer (manufactured by Sysmex Partec $^{\mathrm{R}}$ Germany).Full blood count was carried out on the EDTA anticoagulated sample using the Horiba Abx Micros 60 Haematology Analyser (manufactured by Horiba instruments incorporated ${ }^{\mathrm{R}}$ USA). Results: The D-dimer level was found to be lower in HAART- experienced subjects $(288.35 \pm 129.12 \mathrm{ng} / \mathrm{ml})$ than HAART-naïve subjects $(389.85 \pm$ $217.61 \mathrm{ng} / \mathrm{ml}$.) $(\mathrm{P}=0.013)$. There was no increase in haematocrit, while the mean WBC count showed increase in the HAART-experienced compared to HAART-naïve subjects. Platelet counts were also increased in the HAARTexperienced subjects in comparison to HAART-naïve subjects. Conclusion: This study suggests that D-dimer levels are higher in HIV treatment-naïve patients compared to treatment- experienced patients.

Keywords: Human immunodeficiency virus, Treatment-naive, Treatment-experienced, D-dimer.

Copyright @ 2020: This is an open-access article distributed under the terms of the Creative Commons Attribution license which permits unrestricted use, distribution, and reproduction in any medium for non-commercial use (NonCommercial, or CC-BY-NC) provided the original author and source are credited.

\section{INTRODUCTION}

Globally, an estimated 35.3 (32.2-38.8) million people were living with HIV in 2012. An increase from previous years as more people are receiving the lifesaving antiretroviral therapy. There were 2.3 (1.9-2.7) million new HIV infections globally, showing a 33\% decline in the number of new infections from 3.4 (3.13.7) million in 2001. At the same time the number of AIDS deaths is also declining with 1.6 (1.4-1.9) million AIDS death in 2012, down from 2.3 (2.1-2.6) million in 2005[1].

A comprehensive survey conducted in 2012, (NARHS plus II 2012) showed a decline in HIV prevalence in Nigeria to $3.4 \%$ from $4.1 \%$ in 2011. Similarly, based on projected HIV estimates for 2013, about $3,229,757$ people live with HIV while it is estimated that 220,394 new HIV infections occurred in
2013. A total of 210,031 died from AIDS related cases. It is also estimated that a total of 1,476,741 required antiretroviral (ARV) drugs in 2013 out of which 639,397 are currently receiving treatment [2].

Nigeria's life expectancy has declined significantly. In 1991 the average life expectancy was 54 years for women and 53 years for men [3]. In 2010 the overall life expectancy had fallen to around 51.9 years [4]. Human immunodeficiency virus (HIV) is a retrovirus in the lentivirus family with a diameter of $100 \mathrm{~nm}$. It is a lipid-coated RNA virus with a reverse transcriptase [5]. Two types of HIV exist presentlyHIV-1 and HIV-2 and these two viruses have been identified as the primary cause of Acquired Immunodeficiency Syndrome (AIDS) [6, 7]. HIV-1 was first isolated in the early 1980s and is the major cause of AIDS in the world today [8]. HIV-2 which is 
similar to HIV-1 was later identified in the developing world [9].

Acquired immune deficiency syndrome (AIDS) was first reported in 1981 in Los Angeles, USA. In late 1982, the first cases of AIDS-like illness were reported in transfused patients [10]. By early 1984, the responsible virus, HIV-1, initially called human Tcell lymphotropic virus-1ll (HTLVIII)/lymphadenopathy associated virus (LAV) was identified [10]. HIV can be transmitted by sexual contact with an infected partner, parenteral drug use with a blood-contaminated needle, exposure to infected blood or blood products, and perinatal exposure from an infected mother to her infant [11].

Approximately 80-95 percent of HIV infections in Nigeria are a result of heterosexual sex [12], while transmission through unsafe blood accounts for the second largest source of HIV infection in Nigeria [13]. The prevalence of HIV infection among blood donors varies from one geographical location to another. Egesie et al. in 2011 got a seroprevalence rate of $6.9 \%$ [13] and Ejele et al. in a study in port-harcourt got a seroprevalence rate of $1.4 \%[14]$. Vertical transmission still remains important with around 75,000 babies born with HIV each year in Nigeria [15]. While, there are indications of increasing HIV prevalence among injection drug users (IDU) in Nigeria [16].

HIV infection is known to result in increased levels of proinflammatory cytokines, such as tumor necrosis factor (TNF), interleukin-1 (IL-1), and interleukin-6 (IL-6), which can contribute to the development of a procoagulant state by increased levels of factor VIII and decreased levels of protein S[17,18]. An increased risk of death was found to be associated with higher levels of high-sensitivity $\mathrm{C}$-reactive protein (hs CRP), interleukin 6 (IL-6), and D-dimers and the level of these biomarkers were reduced by effective ARV therapy [19]. Kuller et al. found that HIV-induced activation of inflammation and a hypercoagulable state increases the risk of death among HIV-positive patients, and that interrupting ARV therapy further increases this risk [20]. HIV infection has emerged as a wellrecognized prothrombotic condition. Crum-cianflone et al reported that venous thromboembolism (VTE) occurs more commonly among HIV-infected persons than in the general population, and they often occur in relatively young patients [21].

The mechanism by which HIV infection causes thrombosis is multifactorial and complex. Several coagulation abnormalities have been reported among HIV-infected patients including the presence of antiphospholipid antibodies, increased levels of von Willebrand factor, elevated homocysteine, and deficiencies of protein C, protein S, Antithrombin III, and heparin cofactor II [21].
Activation of monocytes by microbial products and high level of CRP both of which up-regulates expression of tissue factor (TF) has also been proposed as possible mechanism of thrombus formation in HIV $[22,23]$. The hypercoagulable state created by HIV infection might induce thrombus formation and subsequent fibrinolysis will give rise to a raised $D$ dimer level [23].

People with HIV infection and AIDS have an elevated cancer risk [24]. Kaposi's sarcoma and lymphomas are the only HIV-related tumours that have been proven to be procoagulant $[25,26]$.

The Swiss-Thai-Australia Treatment Interruption Trial (STACCATO), in which participants restarted ART when their CD4+ T-cell count fell below 350 cells $/ \mathrm{mm}^{3}$ (rather than 250 cells $/ \mathrm{mm}^{3}$ in SMART), also revealed a link between HIV viral load and inflammation biomarkers. A variety of markers, including D-dimer, VCAM-1, P-selectin, MCP-1, and leptin, decreased as HIV was suppressed on ARV therapy and rose during treatment interruption. In contrast, levels of anti-inflammatory biomarkers, including IL-10 and adiponectin, increased as viral load declined and fell during treatment breaks [27].

Neuhaus et al. in a comparison of inflammation biomarkers in people with and without HIV looked at SMART participants and HIV-negative individuals in two large population-based cardiovascular studies. People with HIV had significantly higher levels of markers including IL-6, CRP, and D-dimer. Levels were higher in HIV-positive participants both on and off ARV therapy compared with HIV-negative people, and this link remained after adjusting for traditional cardiovascular risk factors [28].

The elevation of these biomarkers among HIV infected persons on effective ARV therapy as well as those not on ARV therapies may reflect ongoing immune activation even with successful suppression of HIV replication [29]. Although many pathways have been investigated to determine the mechanism of thrombosis, the only strong evidence available appears to be a protein $\mathrm{S}$ deficiency [30]. Other factors appear to play at least some role, and it appears inevitable that the mechanisms underlying thrombosis associated with HIV infection are multimodal.

HIV-infected persons are now living longer in the era of highly active antiretroviral therapy (HAART), as a result of significant advances in both the understanding of the immunopathogenesis and the clinical management of AIDS [11]. Patients with HIV have multiple risk factors and are at increased risk for VTE, compared with the general population [21]. It is imperative that all risk factors for VTE be identified and incorporated into medical decision making for 
high-risk patients, including those with HIV. There is paucity of literature on D-dimer in HIV positive treatment-experienced and treatment-naïve patients and its value in assessing risk of VTE in HIV patients in this environment.

The aim of this study was to evaluate the Ddimer level in HIV-positive treatment-naïve and treatment-experienced patients. It is hoped that the outcome of this study will add to our knowledge, and at the same time help improve the standard of management of our HIV patients thereby reducing morbidity and mortality.

\section{MATERIALS AND METHODS}

This comparative cross-sectional study was conducted on HIV treatment- experienced patients on HAART, and treatment-naïve HIV patients, all attending HIV clinic at the University of Port-Harcourt Teaching Hospital, Port Harcourt, Rivers state, Nigeria.

Subjects recruited into the study were adult volunteers between the ages of 18 to 65 years with the ability to understand and provide informed consent.

\section{Inclusion criteria for HIV treatment-naïve subjects}

- An established HIV diagnosis (previous documentation)

- Patient has never been on antiretroviral therapy

- Negative plasma pregnancy test for females of child-bearing potential.

\section{Inclusion criteria for HIV treatment-experienced} subjects

- An established HIV diagnosis (previous documentation)

- Patient has been on antiretroviral therapy

- Negative plasma pregnancy test for females of child-bearing potential.

\section{Exclusion criteria from the study}

- $<18$ or $>65$ years.

- History of an existing liver disease.

- Essential hypertension.

- Insulin and non-insulin dependent diabetes mellitus.

- Pregnant or breast feeding females (negative plasma pregnancy test).

- Women on oral contraceptive pills.

- Known bleeding or clotting disorders including history of deep vein thrombosis, pulmonary embolism or haemophilia.

- Hepatitis B or hepatitis C infection.

- Current use of anticoagulant therapy.

- Concurrent malignancy, requiring cytotoxic chemotherapy or radiation therapy.

- Nephrotic syndrome
A written consent was obtained from each participant, who was asked to fill the structured questionnaires to obtain demographic data, with assistance given, if necessary.

Blood was collected after the relevant information was recorded in the questionnaire.

\section{Sample size Determination}

The sample size expression $\mathrm{n}=\frac{\mathrm{Z}^{2} \mathrm{pq}}{\mathrm{d}^{2}}$

This formula was used to determine the minimum sample size 186

Where $\mathrm{n}=$ the desired sample size (when population is greater than 10000).

$\mathrm{Z}=$ the standard normal deviation, usually set at 1.96 which corresponds to the $95 \%$ confidence interval.

$\mathrm{P}=$ the proportion in the target population estimated to have a particular characteristic. In this case a reasonable estimate was $0.02(2 \%)$.This reasonable estimate was chosen based on prevalence of.

$.0 .19-7.63 \% / y e a r$, with most literature citing $1-2 \%$ of VTE in HIV patients 19, 20, 10, 9,110,111,112,113

$\mathrm{q}=1.0-\mathrm{p}=1.0-0.02=0.98$

$\mathrm{d}=$ degree of accuracy (precision), usually set at 0.05 .

Thus $\mathrm{n}=\underline{(1.96)^{2}(0.02)(0.98)} \quad=30.118144$

$$
(0.05)^{2}
$$

The minimum sample size calculated for the study was 30 . However, a total of 80 participants were recruited for the study-40 HIV treatment-experienced patients and $40 \mathrm{HIV}$ treatment-naïve patients.

\section{METHODOLOGY}

A commercial assay kit; ELISA Kit for DDimer (D2D) manufactured by Uscn Life Science Incorporated $^{\mathrm{R}}$ USA was used to determine the D-dimer level. A TC96+ ELISA microplate reader manufactured by Ceco diagnostic ${ }^{R}$ USA was also used for the assay.

Data was analysed using statistical software package-SPSS version 20, Microsoft excel spread sheet. Descriptive and inferential statistics (Student T-test, Analysis of Variance (ANOVA), and Chi Square, Pearson correlation coefficient ( $r$ ) were used as appropriate. $\mathrm{P}$-values $\leq 0.05$ shall be used to define level of significance.

\section{RESULTS}

Eighty (80) HIV-positive adults were enrolled, 40 receiving HAART (HAART-experienced) and 40 who had never been exposed to HAART (HAART- 
Akhidue DO et al., Sch Bull, March 2020; 6(3): 53-59

naïve). The HIV positive subjects have a total of 32 males and 48 females. Both HAART-naive and HAART-experienced subjects have 16 males (40\%) and 24 females $(60 \%)$ each. The HAART-naïve and experienced subjects were mainly business men and women with $70 \%$ and $67.5 \%$ respectively.

The ages of the HAART-naïve and experienced subjects ranged from 18 to 59 years with a mean age of $35.16 \pm 7.82$ years. There was no significant difference between the mean ages of HAART-naïve (34.55 \pm 9.08 years) and HAART-experienced subjects (35.78 \pm 6.37 years), $\mathrm{P}=0.487$. The majority of the subjects $(47.5 \%)$ are in the age range of 26-35 years giving the highest prevalence of HIV positive subjects at $47.5 \%$ in this age group. There is no significant difference between mean ages of male $(37.22 \pm 7.81$ years) and female $(33.79 \pm 7.60$ years $)$ subjects, $\mathrm{P}=0.56$.Table 1 .

On the influence of HAART status on D-dimer level, mean D-dimer level was found to be significantly higher in HAART-naïve subjects than HAARTexperienced subjects, $389.85 \pm 217.61 \mathrm{ng} / \mathrm{ml}$ and $288.35 \pm 129.12 \mathrm{ng} / \mathrm{ml}$ respectively, $\mathrm{P}=0.013$ Table 2 .

Table-1

\begin{tabular}{|c|c|c|c|c|c|c|c|}
\hline & \multicolumn{2}{|c|}{$\begin{array}{l}\text { HAART- } \\
\text { NAIVE }\end{array}$} & \multicolumn{2}{|c|}{$\begin{array}{c}\text { HAART- } \\
\text { EXPERIENCED }\end{array}$} & & \\
\hline & & $\mathbf{N}$ & $(\%)$ & $\mathbf{N}$ & $(\%)$ & & \\
\hline \multirow[t]{5}{*}{ Age Group (years) } & $18-25$ & 7 & $(17.5)$ & 1 & $(2.5)$ & \multirow[t]{5}{*}{6.182} & \multirow[t]{5}{*}{$0.166^{+}$} \\
\hline & $26-35$ & 17 & $(42.5)$ & 21 & $(52.5)$ & & \\
\hline & $36-45$ & 11 & $(27.5)$ & 14 & $(35.0)$ & & \\
\hline & $46-55$ & 4 & $(10.0)$ & 4 & $(10.0)$ & & \\
\hline & $56-60$ & 1 & $(2.5)$ & 0 & $(0.0)$ & & \\
\hline \multirow[t]{2}{*}{ Sex } & Male & 16 & $(40.0)$ & 16 & $(40.0)$ & \multirow[t]{2}{*}{0.000} & \multirow[t]{2}{*}{1.000} \\
\hline & Female & 24 & $(60.0)$ & 24 & $(60.0)$ & & \\
\hline \multirow[t]{8}{*}{ Occupation } & CIVIL SERVANT & 6 & $(15.0)$ & 5 & $(12.5)$ & \multirow[t]{8}{*}{4.970} & \multirow[t]{8}{*}{$0.823^{+}$} \\
\hline & CLERGY & 0 & $(0.0)$ & 1 & $(2.5)$ & & \\
\hline & HOUSE HELP & 1 & $(2.5)$ & 0 & $(0.0)$ & & \\
\hline & HOUSEWIFE & 0 & $(0.0)$ & 2 & $(5.0)$ & & \\
\hline & RETIRED TEACHER & 0 & $(0.0)$ & 1 & $(2.5)$ & & \\
\hline & STUDENT & 2 & $(5.0)$ & 2 & $(5.0)$ & & \\
\hline & TRADER & 28 & $(70.0)$ & 27 & $(67.5)$ & & \\
\hline & UNEMPLOYED & 3 & $(7.5)$ & 2 & $(5.0)$ & & \\
\hline \multirow[t]{2}{*}{ Do you take alcohol? } & $\mathrm{NO}$ & 19 & $(47.5)$ & 28 & $(70.0)$ & \multirow[t]{2}{*}{4.178} & \multirow[t]{2}{*}{$0.041^{*}$} \\
\hline & YES & 21 & $(52.5)$ & 12 & $(30.0)$ & & \\
\hline \multirow[t]{2}{*}{ Do you Smoke? } & $\mathrm{NO}$ & 38 & $(95.0)$ & 39 & $(97.5)$ & \multirow[t]{2}{*}{0.346} & \multirow[t]{2}{*}{0.556} \\
\hline & YES & 2 & $(5.0)$ & 1 & $(2.5)$ & & \\
\hline \multirow{4}{*}{$\begin{array}{l}\text { BMI Class } \\
\text { Weight/Height }^{2} \\
\left(\mathrm{Kg} / \mathrm{m}^{2}\right)\end{array}$} & Underweight $(<18.5)$ & 8 & $(20.0)$ & 5 & $(12.5)$ & \multirow[t]{4}{*}{1.245} & \multirow[t]{4}{*}{0.742} \\
\hline & Normal Weight (18.5-24.9) & 20 & $(50.0)$ & 20 & $(50.0)$ & & \\
\hline & Overweight(25-29.9) & 9 & $(22.5)$ & 10 & $(25.0)$ & & \\
\hline & Obese $(\geq 30)$ & 3 & $(7.5)$ & 5 & $(12.5)$ & & \\
\hline
\end{tabular}

Table-2

\begin{tabular}{|l|l|l|l|l|}
\hline Parameter & $\begin{array}{l}\text { HAART-Naïve N=40 } \\
\text { Mean }( \pm \text { SD })\end{array}$ & $\begin{array}{l}\text { HAART-Experienced N=40 } \\
\text { Mean }( \pm \text { SD })\end{array}$ & $\mathrm{t}$ & P-value \\
\hline D-dimer $(\mathrm{ng} / \mathrm{ml})$ & $389.85( \pm 217.61)$ & $288.35( \pm 129.12)$ & 2.537 & $0.013^{*}$ \\
\hline
\end{tabular}

\section{DISCUSSION}

The purpose of this study was to assess Ddimer levels in HIV treatment-naïve and treatmentexperienced patients in Port-Harcourt, Nigeria.

Several studies have shown that D-dimer levels are elevated in HIV infection and that the high levels of D-dimer observed in HAART-naïve patients is reduced by effective ARV therapy [19, 27, 28, 29]. HIV infection is a well-recognized prothrombotic condition and D-dimer has also been associated with several clinical outcomes, including venous thromboembolism (VTE), cardiovascular disease (CVD), and all-cause mortality [20, 31].

In this study, the D-dimer level was found to be significantly elevated in HIV treatment-naïve subjects in comparison to the HIV treatmentexperienced subjects $(\mathrm{P}=0.013)$. The mean $\mathrm{D}$-dimer level of HAART-naïve subjects was $389.85 \pm 217.61 \mathrm{ng} / \mathrm{ml}$ and in HAART- experienced subjects was $288.35 \pm 129.12 \mathrm{ng} / \mathrm{ml}$. The observed D- 
dimer levels elevation in HIV infection in this study is in keeping with previous studies by Kuller[20], Neuhaus[28], Baker [32], Musselwhite et al. [31] and others.

A strong association between HIV replication and raised D-dimer levels has been demonstrated. Baker et al found that levels of IL-6, ${ }_{5}$ ICAM-1 and D-dimer were $65-70 \%$ higher in HIV-infected participants $(\mathrm{P} \leq 0.02$ for all markers) than uninfected controls and these were statistically significantly higher in the HIVinfected study subjects than control [32]. Neuhaus et al. in a comparison of $\mathrm{HIV}$-infected participants from SMART with matched control subjects from the Coronary Artery Risk Development in Young Adult study (CARDIA) and multi-ethnic study of Atherosclerosis (MESA), levels of hsCRP, IL-6 and Ddimer ranged from $50 \%$ to over $100 \%$ higher in individuals with HIV infection [28]. Kuller et al. suggested that increase in D-dimer level could be as a result of HIV replication with induced activation of inflammatory and coagulation pathways [20]. The mechanisms involved are multifactorial and complex.

Highly active antiretroviral therapy (HAART) can suppress HIV replication for extended periods resulting in substantial reductions in chronic immune system activation and inflammatory cytokine production leading to a reduction in D-dimer levels and mortality in HAART-experienced patients [32].

Several studies have indicated that HAART reduces the level of biomarkers, including D-dimer, in HIV patients. El-Sadr et al. found that levels of hs CRP, IL-6 and D-dimer were reduced by effective ARV therapy [19]. Baker et al observed a significant reduction in D-dimer but not IL-6 and hs CRP after starting ARV therapy, while interruption of ARV therapy led to an increase in these biomarkers [32]. Kuller et al. also demonstrated an increase in these biomarkers upon discontinuation of ARV therapy, and the increase was found to be associated with an increase in HIV-RNA levels [20]. In other studies by Hougaard et al. [33], Hamlyn et al. [34], Kaplan et al. [35] and in the STACCATO trial [35]. Reduced D-dimer levels were also observed in HIV treatment-experienced patients on HAART.

Neuhaus et al. in a comparison of inflammation biomarkers observed a significantly higher level of markers including IL-6, CRP and Ddimer in HIV positive subjects both on and off ARV therapy compared with HIV negative control, suggesting that viral suppression alone may not be sufficient to counter the factors driving inflammation in this population [28].
The elevation of D-dimer level observed in HAART-naïve subjects in comparison to HAARTexperienced subjects in this study is in support of existing literatures. Data from this study also suggest that HAART reduced D-dimer level significantly in HAART-experienced subjects, thereby reducing the risk of thrombosis. This study has been able to document the presence of elevated D-dimer level among HIV treatment-naïve and treatment-experienced patients in Port-Harcourt, Nigeria.

\section{CONCLUSION}

The study has been able to document the presence of elevated D-dimer level among HIV treatment-naïve patients in comparison to HIV treatment-experienced patients in Port-Harcourt, Nigeria. Data from this study also suggest that HAART reduces D-dimer level significantly in HAARTexperienced subjects, thereby reducing the risk of thrombosis. These findings are in support of existing literatures.

\section{RECOMMENDATION}

Since the subjects in this present study are few, a cohort study using a larger population to confirm these findings is recommended.

It is suggested that D-dimer should also be further studied to ascertain its usefulness in assessing risk of thrombosis in HIV infection.

Finally, a risk stratification system or screening tool for VTE should be developed for HIV patients, as this will help to reduce morbidity and mortality. This system should involve CD4+ T-cell count and D-dimer assay, since these investigations are less expensive and easily accessible in a resourceconstrained environment like Nigeria.

\section{LIMITATIONS OF STUDY}

- Cross-sectional study design which resulted in our inability to describe associations for D-dimer level and CD4 count overtime (unable to account for variations over time).

- As a consequence of the small sample size some associations may have been missed.

\section{REFERENCES}

1. Joint United Nations Programme on HIV/AIDS (UNAIDS): Report on the Global AIDS Epidemic. (2010). Epidemic update: Available; http://www.unaids.org/sites/default/files/media_ass et/20101123_globalreport_en_1.pdf;1661.Accessed $12^{\text {th }}$ December 2011.

2. Global AIDS response progress report (GARPR). (2012). January-December 2011 reporting period. National Agency for the Control of AIDS Federal Republic of Nigeria; 15-18. 
Akhidue DO et al., Sch Bull, March 2020; 6(3): 53-59

3. USAID|Nigeria. (2012). HIV/AIDS and Tuberculosis: Available; http://nigeria.usaid.gov/program/3. Accessed 12th June 2012.

4. UNDP. (2011). Human Development Report 2011. Available;

http://hdrstats.undp.org/en/countries/profiles/NGA. html. Accessed 12th June 2012.

5. Hoffmann, C., Rockstroh, J.K., HIV Medicine. (2011). Available; www.hivbook.com. Accessed on the 12th December 2011.

6. Alizon, S., Von Wyl, V., Stadler, T., Kouyos, D.R., Yerly, S. (2010).The Swiss HIV Cohort study (2010). Phylogenetic approach reveals that virus genotype largely determines HIV set-point viral load. PLOS pathogens; 6(9), e1001123.

7. Adoga, M.P., Nimzing, L., Mawak, J.D., Agwale, S.M. (2010). Human Immunodeficiency Virus Types 1 and 2: Sero-prevalence and Risk Factors Among a Nigerian Rural Population of Women of Child-bearing Age. SEMJ, 11(1):29-33.

8. Barre-Sinoussi, F., Cherman, J.C., Rey, F., Nugeyre, M.T., Chamaret, S.(1983). Isolation of a T-lymphotrophic retrovirus from a patient at risk for acquired immune deficiency syndrome (AIDS). Science. 220:868-871.

9. Clavel, F., Guetard, D., Brun-Vezinet, F., Chamaret, S., Rey, M.A.(1986). Isolation of a new human retrovirus from West African patients with AIDS. Science, 233: 343-346.

10. Evatt, B.L.(2006). The tragic history of AIDS in the hemophilia population, 1982-1984. J Thromb Haemost, 4(11): 2295-2301.

11. Reid, G.E.(2010). Hematologic manifestation of acquired immunodeficiency syndrome: Williams hematology $8^{\text {th }}$ edition,New York Mc graw-Hill, 1175-1198.

12. United Nations General Assembly Special Session (UNGASS): Country progress report: Nigeria 2010.Available;

http://data.unaids.org/pub/Report/2010/nigeria_201 0_country_progress_report_en.pdf. Accessed 12th June 2012.

13. Egesie, J., \& Egesie, G. (2011). Seroprevalence of Human Immunodeficiency Virus (HIV) Among Blood Donors in Jos - Nigeria, HIV-infection Impact, Awareness and Social Implications of living with HIV/AIDS, Eugenia Barros (Ed.), InTech, Available from: http://www.intechopen.com/books/hiv-infectionimpact-awareness-and-social-implications-ofliving-with-hiv-aids/seroprevalence-of-humanimmunodeficiency-virus-hiv-among-blood-donorsin-jos-nigeria.Accessed 28th June 2012.

14. Ejele, O.A., Erhabor, O., Nwauche, C.A. (2005). Trends in the prevalence of some transfusion transmissible infections among blood donors in port-harcourt, Nigeria. Haema; 8:273-277.
15. WHO/UNAIDS/UNICEF. (2011). 'Global HIV/AIDS Response: Epidemic update and health sector progress towards Universal Access; 2011'.Available

http://www.who.int/hiv/pub/progress_report2011/e n/index.html. Accessed 12th June 2012.

16. The World Bank 'West Africa HIV/AIDS Epidemiology and Response Synthesis': 2008; 62. Available;

http://siteresources.worldbank.org/INTHIVAIDS/R esources/375798-

1132695455908/WestAfricaSynthesisNov26.pdf. Accessed 28th June 2012.

17. Levine, A.M., Vigen, C., Gravink, J., Mack, W., Watts, C.H. (2006). Progressive Prothrombotic State in Women with Advancing HIV Disease. JAIDS, 42(5):572-577.

18. Lijfering, W.M., Sprenger, H.G., Georg, R.R., van der Meulen, P.A., van, der, Meer, J.(2008). Relationship between Progression to AIDS and Thrombophilic Abnormalities in HIV Infection. Clin Chem, 54(7): 1226-1233.

19. El-Sadr, W.M., Lundgren, J.D., Neaton, J.D., Gordin, F., Abrams, D.(2006). Strategies for Management of Antiretroviral Therapy (SMART) Study Group, CD4 count-guided interruption of antiretroviral treatment. $N$ Engl $J \mathrm{Med}$, 355(22):2283-2296.

20. Kuller, L.H., Tracy, R., Belloso, W., De, Wit, S., Drummond, F.(2008). INSIGHT SMART Study Group, (2008). Inflammatory and coagulation biomarkers and mortality in patients with HIV infection. PLoS Med, 5(10):e203.

21. Crum-cianflone, N.F., Weekes, J., Bavaro, M. (2008). Review: thromboses among HIV-infected patients during the highly active antiretroviral therapy era. AIDS patient care STDS, 22(10):771778.

22. Funderburg, N.T., Mayne, E., Sieg, S.F., Asaad, R., Jiang, W.(2010). Increased tissue factor expression on circulating monocytes in chronic HIV infection: relationship to in vivo coagulation and immune activation. Blood, 115(2):161-167.

23. Paffen, E., Vos, H.L., Bertina, R.M.(2004). Creactive protein does not directly induce tissue factor in human monocytes. Arterioscler Thromb Vasc Biol, 24:975-981.

24. Engels, E.A., Biggar, R.J., Hall, H.I., Cross, H., Crutchfield, A. (2008). Cancer risk in people infected with human immunodeficiency virus in the United States. Int J Cancer, 123(1):187-194.

25. Sullivan, P.S., Dworkin, M.S., Jones, J.L., Hooper, W.G.(2000). Epidemiology of thrombosis in HIVinfected individuals. The adult/adolescent spectrum of HIV disease project. AIDS; 14:321-324.

26. Saif, M.W., Greenberg, B. (2001). HIV and thrombosis: A review. AIDS Patient Care STDs. 15(1): 15-24. 
27. Ananworanich, J., Gayet-Ageron, A., Le, Braz, M., Prasithsirikul, W., Chetchotisakd, P.(2006). Staccato Study Group; Swiss HIV Cohort Study. CD4-guided scheduled treatment interruptions compared with continuous therapy for patients infected with HIV-1: results of the Staccato randomised trial. Lancet; 368:459-465.

28. Neuhaus, J., Jacobs, D.R., Baker, J.V., Calmy, A., Duprez, D. (2010). For the INSIGHT SMART, MESA and CARDIA Research Groups; Markers of Inflammation, Coagulation and Renal Function Are Elevated in Adults with HIV Infection: J Infect Dis, 201(12): 1788-1795.

29. Sodora, D.L., Silvestri, G. (2008). Immune activation and AIDS pathogenesis. AIDS, 22:439446.

30. Eyal, A., Veller, M. (2009). HIV and venous thrombotic events. S Afr J Surg; 47(2):54-56.

31. Musselwhite, L.W., Sheikh, V., Norton, T.D., Rupert, A., Porter, B.O.(2011). Markers of endothelial dysfunction, coagulation and tissue fibrosis independently predict venous thromboembolism in HIV. AIDS, 25:787-795.

32. Baker, J.V., Neuhaus, J., Duprez, D., Kuller, L.H., Russell, T. (2011). Changes in Inflammatory and Coagulation Biomarkers: JAIDS, 56(1):36-43.

33. Haugaard, A.K., Lund, T.T., Birch, C., Rönsholt, F., Trøseid, M. (2013). Discrepant coagulation profile in HIV infection: elevated D-dimer but impaired platelet aggregation and clot initiation. AIDS, 27(17):2749-2758.

34. Hamlyn, E., Fidler, S., Stöhr, W., Cooper, D.A., Tambussi, G. (2014). Interleukin-6 and D-dimer levels at seroconversion as predictors of HIV-1 disease progression for SPARTAC Trial Investigators. AIDS, 28:869-874.

35. Kaplan, R.C, Landay, A.L., Hodis, H.N., Gange, S.J., Norris, P.J. (2012). Potential cardiovascular disease risk markers among HIV-infected women initiating antiretroviral treatment. JAIDS, 60(4): 359-368. 